\title{
Microbiological Quality of the Effluents Produced by the University and Hospital Centres in the Department of Littoral, Republic of Benin
}

\author{
Judicaël Todedji ${ }^{1}$, Cyriaque Degbey ${ }^{1,2^{*}}$ (D), Evelyne Soclo ${ }^{1}$, Arouna Yessoufou ${ }^{3}$, \\ Jean Wilfried Hounfodji ${ }^{4}$, Ferdinand Goudjo5, Fidèle Suanon ${ }^{3}$, Daouda Mama ${ }^{3}$ \\ ${ }^{1}$ Regional Institute of Public Health, University of Abomey-Calavi, Ouidah, Benin \\ ${ }^{2}$ University Hospital Hygiene Clinic, National University Hospital Center Hubert Koutoukou MAGA, Cotonou, Benin \\ ${ }^{3}$ Laboratory of Applied Hydrology, University of Abomey-Calavi, Abomey-Calavi, Benin \\ ${ }^{4}$ Laboratory of Theoretical Chemistry and Molecular Spectroscopy, Faculty of Science and Technology, University of \\ Abomey-Calavi, Abomey-Calavi, Benin \\ ${ }^{5}$ Inorganic Chemistry and Environment Laboratory, Faculty of Science and Technology, University of Abomey-Calavi, \\ Abomey-Calavi, Benin \\ Email: *comlancy@yahoo.fr
}

How to cite this paper: Todedji, J., Degbey, C., Soclo, E., Yessoufou, A., Hounfodji, J.W., Goudjo, F., Suanon, F. and Mama, D. (2020) Microbiological Quality of the Effluents Produced by the University and Hospital Centres in the Department of Littoral, Republic of Benin. Open Journal of Epidemiology, 10, 66-80.

https://doi.org/10.4236/ojepi.2020.101006

Received: December 13, 2019

Accepted: February 2, 2020

Published: February 5, 2020

Copyright $\odot 2020$ by author(s) and Scientific Research Publishing Inc. This work is licensed under the Creative Commons Attribution International License (CC BY 4.0).

http://creativecommons.org/licenses/by/4.0/ (c) (i) Open Access

\begin{abstract}
Introduction: The effluents generated by hospital activities pose a potential danger to health and the environment. This study aimed to study the microbiological quality of the effluents produced by the university and hospital centres of Littoral department. Methods: This was a descriptive cross-sectional study of 60 samples of hospital effluents from sewage treatment plants and septic tanks carried out during the period from April to June 2019. Samples at the station were made at the entrance and exit of the station. Samples for microbiological analysis were collected in pre-sterilized $500 \mathrm{~mL}$ glass bottles. Samples were kept between at $2^{\circ} \mathrm{C}-8^{\circ} \mathrm{C}$ and in the dark to ensure satisfactory preservation. ANOVA one-way analysis of variance was performed for each microbiological parameter and principal component analysis (PCA) was also performed. Results: The bacteriological analyses carried out on the 60 samples taken showed a significant microbiological load. In fact, the bacteriological parameters measured and compared to the pollutant release standards in the environment show that the number of germs identified is above the recommended guideline values. The average values for total coliforms, faecal coliforms, faecal streptococci and staphylococci were: $3.91 \times 10^{5} \mathrm{UFC} / 100 \mathrm{~mL}$, $0.52 \times 10^{5} \mathrm{UFC} / 100 \mathrm{~mL}, 3.92 \times 10^{5} \mathrm{UFC} / 100 \mathrm{~mL}$ and $1.36 \times 10^{5} \mathrm{UFC} / 100 \mathrm{~mL}$, respectively. The most isolated bacteria were: Klebsiella pneumoniae, Kleb-
\end{abstract}


siella oxytoca, Escherichia coli, Enterococcus faecalis, Enterobacter cloacae, Pseudomonas horizyhabitans, Staphylococcus aureus and Staphylococcus saprophyticus. Most strains were resistant to at least 3 families of antibiotics (beta-lactams, aminoglycosides and fluoroquinolones). Conclusion: These effluents therefore present health and environmental risks. It is of utmost importance to develop methods for the treatment of these effluents before their release into the natural environment.

\section{Keywords}

Hospital Effluents, Germs, Contamination, University Hospital Center, Benin

\section{Introduction}

Water is a natural resource, precious and essential to life. Most human activities that use water produce wastewater that can contain a broad range of substances as well as multiple pathogenic microorganisms that pose risks to human health and threaten the environment. As the demand for water increases, the amount of wastewater produced and its overall pollutant load are steadily increasing worldwide [1]. Water is an essential element in the hygiene and functioning of health facilities. For each patient, the hospital consumes about one cubic meter of water depending on the type of activity. Healthcare facilities generate liquid waste that is the result of specific activities related to care, testing and/or research [2]. A wide variety of medical products (antibiotics, solvents, heavy metals, radioelements, and medicines) and also cleaning and disinfecting products are likely to end up in the wastewater of these establishments. This chemical pollution is accompanied by biological pollution from excreta of patients (fungi, bacteria sometimes resistant to antibiotics, viruses and parasites). The fate of the substances present in the liquid discharges of health centres must be taken into consideration in order to assess their impact on the environment. Some of these substances tend to persist even after advanced sewage treatment by treatment plants, and can contribute significantly to the spread of antimicrobial resistant bacteria and genes. Thus, the centre must be interested in better management of this pollutant flow [3]. The management of effluents generated by hospitals is a real problem in developing countries, where polluted water treatment and treatment plants (WWTPs), which are often non-existent, are of limited treatment capacity and of dubious efficiency, thus making it possible for pollutants and pathogens to escape in the natural environment. The effluents generated by hospital activities present a potential danger for humans and their environment [4] [5]. Despite the health and environmental risks presented by the latter, these effluents are continuously discharged into natural water reserves such as lagoon, lakes, ponds and the sea, and sewage sludge is used as a soil amendment, mainly for gardening. The local flora and fauna are permanently threatened by the release of hospital effluents into the environment without any prior treatment. In- 
deed, the specificity of hospital effluents is linked to their high degree of toxicity. Even at very low concentrations, the substances contained in hospital effluents can affect animals' well-being: estrogens, for example, can make fish hermaphrodite [6]. The cumulative and synergistic effects of substances contained in hospital effluents often disturb the normal metabolisms of organisms and can induce the proliferation of bacterial strains and their resistance to antibiotics [7]. Waste generated by hospital activities is a reservoir of potentially dangerous micro-organisms that can infect patients, staff and the general public [8]. Hospital effluents are 5 to 15 times more ecotoxic than urban effluents [9].

Benin has six University Hospital Centres (CHU) in the Littoral Department, the largest of them is the National University Hospital Centre Hubert Koutoucou MAGA (CNHU-HKM) located in Cotonou town; It has an activated sludge treatment plant which unfortunately does not function anymore [10] [11]. At the level of health facilities that do not have a treatment plant, liquid waste is dumped into the washbasins and drained to septic tanks and sumps, passing by open eye collectors. Most of these septic tanks and sumps are full-bleed and, through the infiltration process, these effluents can contaminate shallow groundwater [12] [13]. When these septic tanks are filled, the managers of these hospitals use private drainage facilities. These private structures will then empty this waste to the SIBEAU station. According to the managing direction of SIBEAU waste treatment plant, the characteristics of the sewage of the entrance (Effluent) are much the same with that of the exit (effluent). Despite all the above-mentioned observations, the wastewater from the installations is permanently discharged into natural water reserves such as Nokoué Lake or into the sea [11]. These surface waters are, however, an important source to supply of fish products in Benin. Such a situation presents ecotoxicological risks and threatens the health of populations; since the pollutants in these effluents can enter the food chain through fish and other aquatic products [11]. It appears thus necessary to develop methods for treating these effluents before their release into the natural environment. Thus, eliminating micropollutants is a major challenge for the scientific community.

In this context, the issue related to the discharge of hospital effluents is becoming more and more important. Benin's water reservoirs (rivers, lakes) and especially the hospital wastewater deserve special attention. It is of paramount importance to know the quality of the effluent discharged into the receiving environment. Accordingly, the present research work aimed at evaluating the microbiological quality of the effluents produced by the University's Hospital and Centres in the department of Littoral.

\section{Material and Methods}

\subsection{Study Area}

The study area includes in the university's hospitals and centres in the department of Littoral. The choice of university hospitals is motivated on the one hand by the fact that they are reference centres for patients, training and learning for 
health professionals; and secondly because they produce a lot of liquid waste in which broad range of pollutants could be found. There are six university's hospitals in the coastal department:

- Hubert Koutoukou MAGA National University Hospital Centre (CNHU-HKM).

- University Hospital Centre of Mother and Child Lagoon (CHU-MEL).

- National Hospital and University Centre of Pneumo-Physiology (CNHPP).

- University Hospital Psychiatric Centre Jacquot (CHUP-Jacquot).

- Army Instructions Hospital and University Hospital of Cotonou (HIA-CHU).

- Suru Léré University Hospital Centre (CHUZ-SL).

For the purposes of this research, we had worked in four of the six university teaching hospitals in the Coastal Department: CNHU-HKM, CHU-MEL, CHUZ-SL, HIA-CHU. These four centres were selected on the one hand because the activities in these centres cover a variety of disciplines, medical and medical-technical services, and on the other hand, they offer a variety of treatment of pathologies. The other two centres are hospital centres for the management of specific pathologies.

The CNHU-HKM sewage collection network is conceived as a sanitary sewer system that is not functioning properly due to the lack of a rainwater sanitation system. CNHU-HKM has a treatment plant. The CHU-MEL has a wastewater treatment plant and also uses the septic system. The treatment plant receives a portion of the wastewater produced by the services. The CHUZ-SL and the HIA-CHU do not have a treatment plant, and the wastewater produced is discharged into the washbasins and drained to the septic tanks.

\subsection{Type of Study and Sampling}

This was a cross-sectional descriptive and analytical study of 60 samples of raw hospital effluents from sewage treatment plants and septic tanks carried out during the period from April to June 2019. The non-probabilistic method with the reasoned technique choice was used for the selection of septic tanks for the services to be sampled. The effluents from the services sampled are those that administer the care and produce more liquid waste and consequently have a greater risk of infection. The CNHU-HKM did not have septic tanks. At the level of university hospitals which use the septic tank system, we have identified all the septic tanks receiving the effluents at each $\mathrm{CHU}$. After the census, we included in our study, the septic tanks receiving the effluents coming from the services administering the care and which produce more liquid waste presenting a greater infectious risk than other services. The number of effluent samples from the septic tanks of CHU-MEL, HIA-CHU and CHUZ-SL were respectively 17, 20 and 19. Four (4) samples were taken at the level of the treatment plants, namely two (2) at the CNHU level and two (2) at the CHU-MEL.

\subsection{Sampling Equipment, Sampling Points, Methods and Frequency of Sampling}

Samples were taken from pre-sterilized $500 \mathrm{~mL}$ glass bottles. At the level of the 
treatment plants, average samples $24 \mathrm{~h}$ were collected. The frequency of sampling was daily at specific times depending on the activities of the hospital: the morning at 7 o'clock, the afternoon at 13 o'clock and the evening at 19 o'clock. These samples were taken at the inlet (before treatment) and at the outlet (after treatment) of the station to assess at each level the quality of the effluent. After collection, the day's samples were combined into a composite sample. A total of four composite samples were made. At the level of septic tanks, these effluents were taken directly into the septic tanks at the end of the day at $19 \mathrm{~h}$. For research of multidrug-resistant bacteria (BMR), the hospital effluent is likely to contain chlorine in large quantities, it may, during transport, continue to exert its action on the bacteria present and it is necessary to destroy it. Thus, we added five drops of sodium thiosulphate to the sample bottles before sterilization in order to reduce the effect of the residual chlorine contained in the wastewater.

\subsection{Sampling Conditions and Transport of Samples}

To ensure the traceability of the sample, at each sampling point is associated with a sampling sheet. Sample conditioning during transport is an important step that can alter the integrity of the samples. In order to prevent the samples from undergoing biological, physical or even chemical transformations, each flask was transported in coolers equipped with frozen accumulators at a temperature between $2^{\circ} \mathrm{C}$ and $8^{\circ} \mathrm{C}$ to cool the samples but also to keep them at protected from light. The samples were analyzed within 48 hours after sampling.

\subsection{Data Processing and Analysis}

It had two parts: a first part was devoted to laboratory analysis and a second part to statistical analysis. Laboratory analyses were carried out at the Public Health Research and Expertise Laboratory of the University Hospital Hygiene Clinic of CNHU-HKM Cotonou.

\subsection{Laboratory Analysis}

\section{$\checkmark$ Microbiological analysis}

It consisted of searching the effluents: total aerobic mesophilic flora (FMAT), total coliforms, faecal coliforms, faecal streptococci, staphylococci, yeasts and clostridium. The bacteriological analyses were made by the membrane filtration method. The analytical methods and conditions used are given in Table 1.

\section{$\checkmark$ Determination of antibiotic resistance patterns}

The antibiograms were made to study the sensitivity of germs to antibiotics. They were carried out by the disk diffusion method according to the standards of the European Committee on Antimicrobial Susceptibility Testing (EUCAST) [14] in order to study the resistance towards families of antibiotics. The antibiogram was used to determine in vitro the resistance pattern of 18 selected antibiotics to represent important chemical families, with different targets and mechanisms of action, namely, beta-lactams, aminoglycosides, macrolides and quinolones. 
Table 1. Incubation conditions, culture media and protocol of analysis of the desired germs.

\begin{tabular}{|c|c|c|c|c|c|c|}
\hline Micro-organisms & Incubation & Culture medium & Volume & Analysis method & Observations & References \\
\hline Total coliforms & $37^{\circ} \mathrm{C}$ for $24 \mathrm{~h}$ & $\begin{array}{l}\text { Lactose agar with TTC } \\
\text { and at the Tergito }\end{array}$ & $100 \mathrm{~mL}$ & $\begin{array}{c}\text { Filtration technique } \\
\text { on } 0.45 \mu \mathrm{m} \text { filter membrane }\end{array}$ & Red colony & $\begin{array}{c}\text { NF EN ISO 9308-3 } \\
(1999)\end{array}$ \\
\hline Faecal coliforms & $44^{\circ} \mathrm{C}$ from 18 à $24 \mathrm{~h}$ & $\begin{array}{l}\text { Lactose agar with TTC } \\
\text { and at the Tergito }\end{array}$ & $100 \mathrm{~mL}$ & $\begin{array}{c}\text { Filtration technique } \\
\text { on } 0.45 \mu \mathrm{m} \text { filter membrane }\end{array}$ & Red colony & $\begin{array}{c}\text { NF EN ISO 9308-3 } \\
(1999)\end{array}$ \\
\hline Faecal streptococci & $37^{\circ} \mathrm{C} / 48 \mathrm{~h}$ & Slanetz-Bartley & $100 \mathrm{~mL}$ & $\begin{array}{c}\text { Filtration technique } \\
\text { on } 0.45 \mu \mathrm{m} \text { filter membrane }\end{array}$ & Red colony & NF ISO 7899-2 \\
\hline Staphylococci & $37^{\circ} \mathrm{C} 24-48 \mathrm{~h}$ & Chapman & $100 \mathrm{~mL}$ & $\begin{array}{c}\text { Filtration technique } \\
\text { on } 0.45 \mu \mathrm{m} \text { filter membrane }\end{array}$ & Red colony & NF T90-412 \\
\hline Clostridium & $24-48 \mathrm{~h}$ & SPS/TSN & $20 \mathrm{~mL}$ & Incorporation into agar & $\begin{array}{l}\text { Black halo of sig- } \\
\text { nificant size }\end{array}$ & NF T 90-415 \\
\hline Yeasts & 5 days & $\begin{array}{l}\text { Sabouraud with } \\
\text { chloramphenicol }\end{array}$ & $100 \mathrm{~mL}$ & $\begin{array}{c}\text { Filtration technique } \\
\text { on } 0.45 \mu \mathrm{m} \text { filter membrane }\end{array}$ & - & - \\
\hline
\end{tabular}

\section{Statistical analysis}

The various statistical analyses were carried out with SPSS software, version 21 and OriginPro 9.0. The average concentrations of microbiological parameters were calculated and compared to the guide values of the World Health Organization [15] and those of Benin [16]. In order to compare the results of the four CHUs with each other, a one-way analysis of variance (ANOVA One Way) was performed for each microbiological parameter, after checking the normality and homoscedasticity of the data. From principal component analysis (PCA), the plotting of the factorial map, the correlation between the different parameters and the classification of the sampling points according to the microbiological parameters were established at the significance level $\alpha=0.05$.

\section{Results}

\subsection{Microbiological Quality of Hospital Effluents}

Table 2 presents the average values of the microbiological parameters of the effluents produced by the CHUs. Total and faecal coliforms, faecal streptococci, staphylococci, Clostridium spores and yeasts were found in all samples taken at the four CHUs. The values obtained for these different groups of microorganisms are considerably higher than the WHO standard (2012) for a direct discharge into the environment. The mean values of the measured parameters show a statistically significant difference from one CHU to another $(p<0.05)$ except for staphylococci $(p>0.05)$. The mean values measured at the CNHU-HKM are higher than those measured at the other CHUs.

\subsection{Component Analysis of Microbiological Parameters on All Samples}

The Principal Component Analysis (PCA) was performed to highlight the relationships that exist between the different microbiological parameters at the sampling points (Figure 1). The factorial design summarized $76.52 \%$ of the overall 
Table 2. Mean values followed by standard deviation of the microbiological parameters of the effluents produced by the CHUs of the Littoral Department.

\begin{tabular}{|c|c|c|c|c|c|c|c|}
\hline Parameters & Unit & CNHU-HKM & CHU-MEL & HIA-CHU & CHUZ-SL & Average & $\begin{array}{c}\text { Acceptable } \\
\text { Standard (WHO) }\end{array}$ \\
\hline $\operatorname{FMAT}^{\star}\left(10^{5}\right)$ & $\mathrm{UFC} / 100 \mathrm{ml}$ & $2000.00 \pm 418.61$ & $660.68 \pm 311.53$ & $395.95 \pm 403.10$ & $733.89 \pm 702.70$ & $640.27 \pm 566.94$ & \\
\hline $\mathrm{CT}^{*}\left(10^{5}\right)$ & $\mathrm{UFC} / 100 \mathrm{ml}$ & $16.55 \pm 1.06$ & $4.28 \pm 1.96$ & $3.07 \pm 2.29$ & $3.09 \pm 1.78$ & $3.91 \pm 3.13$ & \\
\hline $\mathrm{CF}^{*}\left(10^{5}\right)$ & $\mathrm{UFC} / 100 \mathrm{ml}$ & $3.39 \pm 0.59$ & $0.50 \pm 0.24$ & $0.40 \pm 0.40$ & $0.36 \pm 0.24$ & $0.52 \pm 0,62$ & $2.10^{3}$ \\
\hline $\mathrm{SF}^{\star}\left(10^{5}\right)$ & $\mathrm{UFC} / 100 \mathrm{ml}$ & $21.7 \pm 8.91$ & $2.85 \pm 2.73$ & $2.68 \pm 1.92$ & $4.41 \pm 2.64$ & $3.92 \pm 4.32$ & \\
\hline Sta $\left(10^{5}\right)$ & $\mathrm{UFC} / 100 \mathrm{ml}$ & $3.25 \pm 0.38$ & $1.30 \pm 0.92$ & $0.86 \pm 1.91$ & $1.76 \pm 1.37$ & $1.36 \pm 1.51$ & \\
\hline $\operatorname{Clos}^{*}\left(10^{5}\right)$ & $\mathrm{UFC} / 100 \mathrm{ml}$ & $0.16 \pm 0.05$ & $0.03 \pm 0.03$ & $0.05 \pm 0.06$ & $0.01 \pm 0.02$ & $0.04 \pm 0.05$ & \\
\hline $\operatorname{Lev}^{\star}\left(10^{5}\right)$ & $\mathrm{UFC} / 100 \mathrm{ml}$ & $53.00 \pm 11.31$ & $4.68 \pm 5.29$ & $1.60 \pm 5.25$ & $0.73 \pm 2.19$ & $4.01 \pm 10.39$ & \\
\hline
\end{tabular}

*Significatif; CFU: Colony Forming Unit; CT: Total Coliforms, CF: Faecal Coliforms, SF: Fecal Streptococci, Sta: Staphylococci, Clos: Clostridium, Lev: Yeast.

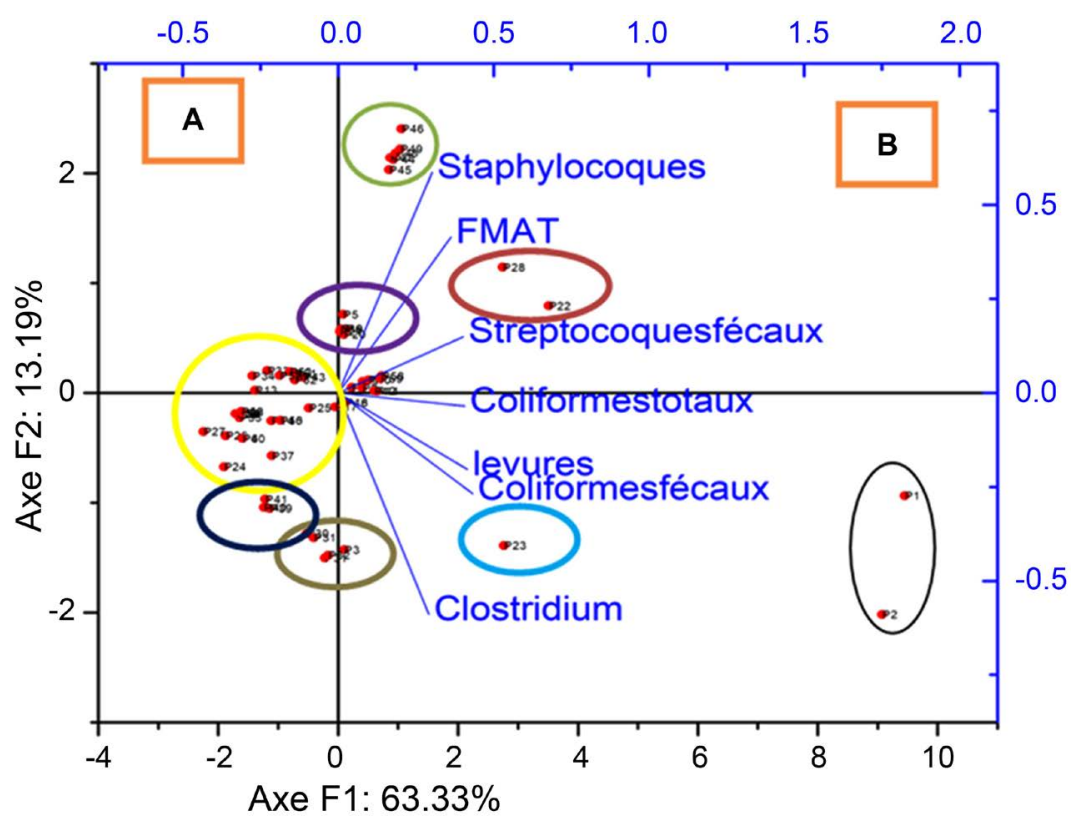

Figure 1. PCA graphical approach of microbiological parameters in water and projection of sampling points in the space of axes F1 and F2. A: left of the factorial plane; B: right of the factorial plane. Points P1 à PointsP60: Different sampling points.

information. The F1 axis, with $63.33 \%$ of the total variance, was represented by fecal coliforms, yeasts, total coliforms, faecal streptococci, FMAT and staphylococci. The faecal streptococci, faecal coliform and total coliform parameters provide information on the degree of fecal pollution of hospital effluents. An increasing fecal contamination gradient was noticed from the negative pole to the positive pole of the axis. This suggests that the pollution was anthropogenic originated. Most of the information provided by the F2 axis (13.19\% variance) was explained by parameters such as staphylococci, FMAT and Clostridiums. Staphylococci and FMAT positively correlated with the F2 axis and clostridium negatively correlated with the F2 axis. 


\subsection{Correlations between Variables}

The study of bivariate linear correlations between the parameters studied gives information on the strength of the associations between them. The matrix of correlations of the 7 parameters measured during our study is presented in $\mathrm{Ta}$ ble 3. In this table, where significant Pearson correlation coefficients $(p<0.01)$ and greater than 0.5 are shown in bold, interesting correlations are observed. Thus, there is a positive correlation between FMAT and parameters such as total coliforms, faecal coliforms, faecal streptococci and staphylococci. Significantly positive correlations were observed between faecal coliforms, faecal streptococci and total coliforms on one hand; and between faecal streptococci, clostridia, yeasts and fecal coliforms in the other hand.

\subsection{Resistance Profile of the Main Identified Bacteria with Antibiotics}

The bacterial species found in the effluents of the hospitals were 24 species. The most isolated bacteria were: Enterococcus faecalis (73.3\%), Klebsiella pneumoniae (56.6\%), Escherichia coli (51.7\%), Staphylococcus saprophyticus (45.0\%), Enterobacter cloacae (38.3\%), Staphylococcus aureus (25.0\%), Citrobacter freundii (16.7\%), Klebsiella oxytoca (11.7\%) and Pseudomonas horizyhabitans (11.7\%) (Table 4).

Analysis of the antibiotic resistance profile of bacteria found in hospital effluents showed that among the 24 bacteria tested, Staphylococcus aureus, Staphylococcus saprophyticus, Enterrocus faecalis, Klebsiella pneumoniae, Citrobacter freundii, Enterobacter cloacae and Escherichia coli were resistant to at least 3 families of antibiotics (beta-lactams, aminoglycosides and fluoroquinolones). The results showed that hospital effluents contain multi-resistant bacteria (BMR) (Table 5).

Table 3. Correlation matrix of microbiological parameters on all samples.

\begin{tabular}{cccccccc}
\hline & FMAT & CT & CF & SF & Sta & Clos & Lev \\
\hline FMAT & 1 & & & & & & \\
CT & $\mathbf{0 . 5 7 7 ^ { * * }}$ & 1 & & & & & \\
CF & $\mathbf{0 . 5 9 5 ^ { * * }}$ & $\mathbf{0 . 7 3 0 ^ { * * }}$ & 1 & & & & \\
SF & $\mathbf{0 . 6 2 6 ^ { * * }}$ & $\mathbf{0 . 7 5 8 ^ { * * }}$ & $\mathbf{0 . 7 2 9 * *}$ & 1 & & & \\
Sta & $\mathbf{0 . 6 2 2 ^ { * * }}$ & 0.424 & 0.437 & 0.480 & 1 & & \\
Clos & 0.351 & 0.418 & $\mathbf{0 . 6 6 6 ^ { * * }}$ & 0.312 & 0.258 & 1 & \\
Lev & $0.504^{* *}$ & $0.762^{* *}$ & $\mathbf{0 . 8 4 9 * *}$ & 0.711 & 0.438 & 0.511 & 1 \\
\hline
\end{tabular}

${ }^{*}$ The correlation is significant at the 0.01 level. CT: Total Coliforms, CF: Faecal Coliforms, SF: Fecal Streptococci, Sta: Staphylococci, Clos: Clostridium, Lev: Yeast.

Table 4. Frequency of groups of identified bacteria according to their genera and species.

\begin{tabular}{cccc}
\hline Troups & Nype of germs & Number $(\mathrm{n}=60)$ & $\%$ \\
\hline Gram bacteria (-) & & \\
Acinetobacter baumannii & 5 & 8.3 \\
Acinetobacter calcoaceticus & 2 & 3.3 \\
\hline
\end{tabular}




\section{Continued}

\begin{tabular}{|c|c|c|c|}
\hline & & & \\
\hline & Citrobacter brakii & 1 & 1.7 \\
\hline & Citrobacter freundii & 10 & 16.7 \\
\hline & Enterobacter aerogenes & 1 & 1.7 \\
\hline & Enterobacter cloacae & 23 & 38.3 \\
\hline & Enterobacter faecalis & 1 & 1.7 \\
\hline & Enterobacter sakazakii & 1 & 1.7 \\
\hline & Escherichia coli & 31 & 51.7 \\
\hline & Klebsiella pneumoniae & 34 & 56.7 \\
\hline & Klebsiella oxytoca & 7 & 11.7 \\
\hline & Raoultella terrigena & 3 & 5.0 \\
\hline & Serratia ficaria & 1 & 1.7 \\
\hline & Serratia fonticola & 6 & 10.0 \\
\hline & Serratia odorifera & 3 & 5.0 \\
\hline & Pantoea spp2 & 3 & 5.0 \\
\hline & Pseudomonas horizyhabitans & 7 & 11.7 \\
\hline \multicolumn{4}{|c|}{ Gram bacteria $(+)$} \\
\hline \multicolumn{4}{|c|}{ Bacillus Gram (+) } \\
\hline Cocci Gram (+)s & Bacillus Gram + with bacillus morphology & 17 & 28.3 \\
\hline \multirow[t]{2}{*}{ Enterococci } & Enterococcus faecalis & 44 & 73.3 \\
\hline & Staphylococcus saprophyticus & 27 & 45.0 \\
\hline \multirow[t]{2}{*}{ Staphylococci } & Staphylococcus aureus & 15 & 25.0 \\
\hline & Staphylococcus epidermidis & 3 & 5.0 \\
\hline Yeasts & Candida $s p$ & 12 & 20.0 \\
\hline
\end{tabular}

Table 5. Resistance rate of the main antibiotic germs.

\begin{tabular}{|c|c|c|c|c|c|c|c|c|}
\hline \multirow[t]{2}{*}{ Antibiotics } & \multicolumn{8}{|c|}{ Number of resistant strains $(\mathrm{I}+\mathrm{R} \%)$} \\
\hline & $\begin{array}{l}\text { Citrobacter } \\
\text { freundii } \\
(\mathrm{n}=10)\end{array}$ & $\begin{array}{c}\text { Enterobacter } \\
\text { cloacae } \\
(\mathrm{n}=23)\end{array}$ & $\begin{array}{l}\text { Escherichia } \\
\text { coli }(\mathrm{n}=31)\end{array}$ & $\begin{array}{c}\text { Klebsiella } \\
\text { pneumoniae } \\
\quad(\mathrm{n}=34)\end{array}$ & $\begin{array}{c}\text { Klebsiella } \\
\text { oxytoca } \\
(\mathrm{n}=7)\end{array}$ & $\begin{array}{c}\text { Enterococcus } \\
\text { faecalis }(\mathrm{n}=44)\end{array}$ & $\begin{array}{c}\text { Staphylococcus } \\
\text { saprophyticus } \\
(\mathrm{n}=27)\end{array}$ & $\begin{array}{l}\text { Staphylococcus } \\
\text { aureus }(\mathrm{n}=15)\end{array}$ \\
\hline Cefixime & $10(100)$ & $23(100)$ & $31(100)$ & $34(100)$ & $7(100)$ & $44(100)$ & $27(100)$ & $15(100)$ \\
\hline Gentamicine & $10(100)$ & $23(100)$ & $24(77)$ & $34(100)$ & $3(43)$ & $41(93)$ & $18(67)$ & $15(100)$ \\
\hline $\begin{array}{l}\text { Amoxicillin }+ \\
\text { clavulanic acid }\end{array}$ & $10(100)$ & $23(100)$ & $28(90)$ & $27(79)$ & $7(100)$ & $35(79)$ & $22(81)$ & $15(100)$ \\
\hline Ceftriaxone & $4(40)$ & $19(83)$ & $30(97)$ & $24(71)$ & $5(71)$ & $36(82)$ & $19(70)$ & $15(100)$ \\
\hline Netilmicin & $4(40)$ & $6(26)$ & $8(26)$ & $11(32)$ & $0(0)$ & $44(100)$ & $8(30)$ & $11(73)$ \\
\hline Ciprofloxacin & $10(100)$ & $23(100)$ & $17(55)$ & $34(100)$ & $3(43)$ & $37(84)$ & $20(74)$ & $13(87)$ \\
\hline Piperacillin & $10(100)$ & $23(100)$ & $18(58)$ & $34(100)$ & $7(100)$ & - & - & - \\
\hline Imipenem & $10(100)$ & $23(100)$ & $20(64)$ & $34(100)$ & $4(57)$ & - & - & - \\
\hline levofloxacin & $10(100)$ & $16(70)$ & $23(74)$ & $34(100)$ & $3(43)$ & - & - & - \\
\hline Nalidixic acid & $10(100)$ & $23(100)$ & $31(100)$ & $34(100)$ & $7(100)$ & - & - & - \\
\hline
\end{tabular}




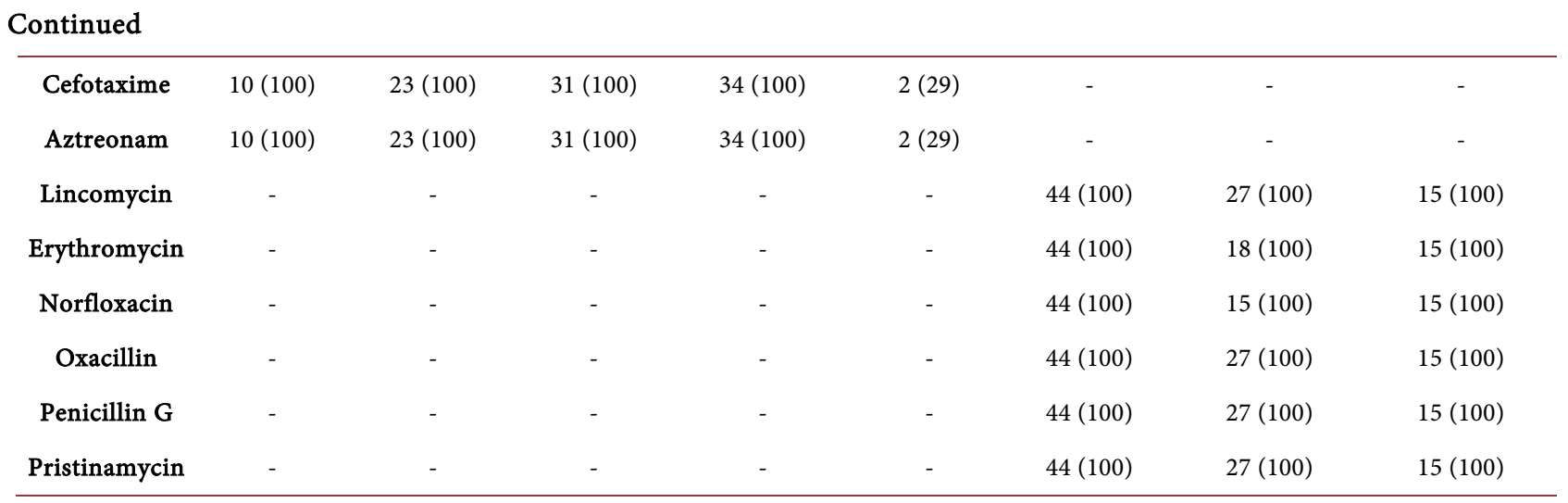

(-) no test.

\section{Discussion}

The effluents produced by hospitals show great variability of characteristics and this variability depends on the size of the hospitals, the number of beds, the number of inpatients and outpatients, the number and type of services, the country and the seasons [17] [18]. This study had shown the microbiological quality of the effluents produced by CHUs in the Department of Littoral and the inherent effects it could have on the receiving environment. From a bacteriological point of view, the presence of pathogenic germs has been demonstrated, such as fecal coliforms, staphylococci, fecal streptococci and clostridium at all sampling sites studied, while the salmonella germ is absent. The results obtained in our study show that the microbial loads of the samples were relatively high. Studies have shown that hospital effluents are highly polluted and if they are discharged into the environment without treatment, they can pose serious risks to human health [9] [10] [11]. As a result, there is a need for stringent treatment and oversight regulations by regulators [19]. The results obtained in our study agree with those of Adanlokonon et al. who reported that the effluents produced by CHU-MEL were highly contaminated by coliform bacteria [9]. These effluents contain a high concentration of fecal coliform and fecal streptococci. The microbiological analysis shows the presence of fecal contamination indicators such as total coliforms, thermo-tolerant coliforms of the Escherichia coli type, faecal streptococci and Clostridium spores. The presence of these indicators shows that the effluents are subject to microbiological pollution of human origin. This state of affairs thus increases the potential epidemiological risk posed by its discharged without treatment [9]. Indeed, the presence of these enterobacteria, although non-pathogenic in their majority, must seriously suspect that of several other pathogenic microorganisms [20]. The FMAT is a good global indicator of faecal pollution. In our study, the average load of FMAT was $640.27 \times 10^{5}$ $\mathrm{cfu} / 100 \mathrm{~mL}$. The average total coliform charge of $3.91 \times 10^{6} \mathrm{CFU} / 100 \mathrm{~mL}$ was higher than that reported by Tahiri et al. [21] on the one hand and Ameziane et al. [22] on the other hand. Emmanuel et al. [23] suggested that fecal coliform concentration may be an indicator of the degree of water pollution and also an 
indirect indicator of the presence or absence of antibiotics or disinfectants. The increase in the value of streptococcus is justified by the nature of the services provided by the hospital service that deals with infectious diseases. The results of the number of staphylococci have shown that the samples taken are highly contaminated with staphylococci. In the present study, bacterial species such as Enterococcus faecalis (73.3\%), Klebsiella pneumoniae (56.6\%), Escherichia coli (51.7\%), Staphylococcus saprophyticus (45.0\%), Enterobacter cloacae (38.3\%), Staphylococcus aureus (25.0\%) were frequently detected in hospital effluents. The same results were reported in the study conducted by Asfaw et al. in Ethiopia [24]. In addition, a study conducted at Hawassa University Reference Hospital, reported the presence of Salmonella spp., Shigella spp., E. coli and S. aureus in hospital effluents [25].

There was a good correlation between different parameters studied in this work. All parameters positively and significantly correlated with each other $(p<$ $0.05, r^{2}>0.5$ ). Significant and positive correlations were observed between faecal coliforms, faecal streptococci and total coliforms. Nevertheless, total coliforms and faecal streptococci, which constitute faecal coliforms, are the main indicators of faecal contamination. This is justified by the highly significant positive correlation noted between these Enterobacteriaceae. The search for one of these microorganisms would thus make it possible to predict the dynamics of the others and consequently to judge the bacteriological quality of their biotope.

The principal component analysis (PCA) showed that the factorial design summarized $76.52 \%$ of the overall information. The factorial map of the samples confirms that the microbiological quality of hospital effluents varies from one sampling site to another. There is a variation in the degree of pollution from one sampling point to another. The observations corresponding to the sampling points encircled in black, red, blue, green and violet were characterized by strong bacteriological pollution. Compared to other sampling sites, the black circled P1 and $\mathrm{P} 2$ sampling sites represented by the input and output of the CNHU-HKM station had higher values for the total bacterial load that could be explained by the larger size of the hospital, the common drainage of wastewater from the hospital to the plant and the non-functioning of the treatment plant and also because of the large production of liquid waste. Otherwise, the observations corresponding to the sampling points encircled in yellow, dark blue and gray are projected to the left of the factorial plane (A), with effluents characterized by lower bacteriological pollution (Figure 1). Those encircled in red come from VIP hospital rooms and the HIA-CHU block and are less bacteriologically polluted than the CNHU. This contamination of the effluents from HIA hospitalization rooms could be explained by the made the sick from various care services are hospitalized in these rooms and produce a different range of liquid waste. The effluents from the maternity of CHUZ-SL were also heavily contaminated by microbiological germs. This high contamination could be explained by the absence of pretreatment of these effluents before their evacuation into the septic 
tanks. The different results indicate that the biological contaminants could come from common sources and are brought to the receiving system by the common pipelines.

Bacterial resistance to antibiotics has become a matter of great concern worldwide, often attributed to overuse of antibiotics [26]. Germs isolated from the hospital effluents of the CHU Littoral are resistant to several families of antibiotics. Since bacteria from hospital effluents originate from the hospital environment, bacteria have developed a resistance mechanism to withstand the hospital environment. Analysis of the antibiotic resistance profile of bacteria found in hospital effluents showed that bacterial species such as $S$. aureus, $S$. saprophyticus, faecalis enterococci, kebsiella pneumoniae, citrobacter freundii, Enterobacter cloacae and E. coli had resistant to all families of antibiotics tested. The results showed that hospital effluents contain multi-resistant bacteria (BMR). Our results are in agreement with those reported in the literature [22] [27]. Indeed, a study conducted in India showed that germs from sewage treatment plants showed simultaneous resistance for ampicillin, ampicillin with clavulanic acid, cotrimoxazole, tetracycline, with first, second and third generation cephalosporins [27]. The one conducted in Alexandria, Egypt, also showed the presence of antibiotic-resistant extended-spectrum $\beta$-lactamase producing bacteria (ESBL) at the end of the wastewater purification process [22], leading to a risk of spreading in the soil, environment and the subsequent exposure of humans and animals. The observation multi-resistance in our study reflects the presence of BMR in hospital's effluents and hospital. This could be explained on the one hand by the selection pressure practiced by practitioners, and on the other hand by the presence of low concentrations of unmetabolized antibiotics released into hospital effluents. These results are also comparable to those of Islam et al. who found in their work multi-resistant bacteria with 5 families of antibiotics with a $100 \%$ resistance to ciprofloxacin, tetracycline, penicillin and erythromycin [28]. The different phenotypes of multi-resistance could also be explained by the fact that antibiotics are among the most prescribed drugs in $\mathrm{CHUs}$ and among these antibiotics, beta-lactams came first. The presence of multidrug-resistant bacteria in the environment is a major public health concern; because these bacteria can infect humans and animals through the consumption of contaminated food and drinking water, or directly from the environment. The microbiological quality of these effluents can be explained by the strong medical activity that takes place at these hospitals and by the absence of a proper treatment of the effluents produced by the hospitals. In most cases, hospital wastewater was not routinely treated before disposal, posing serious health risks and other environmental threats to surrounding residents. It appears then necessary to develop methods of treating these effluents before their release into the natural environment. This study has two limitations. The first is linked to the sampling method used, which does not allow the results from this study to be generalized to all university hospitals in Benin. The study is limited only to the university hospital centers of the Littoral. The second limitation of this study is 
related to the fact that we took punctual samples. It would be interesting to assess the microbiological quality throughout a year, so this amounts to taking monthly samples but it would involve a lot of financial means.

\section{Conclusion}

Hospital liquid waste management is a very important issue in health facilities. The results of this work made it possible to obtain data on the bacteriological parameters of the effluents produced by the university hospitals of the department of Littoral. The effluents produced by university hospital centres in the coastal department are of poor quality. Most microbiological parameters exceed accepted standards. This shows that these effluents pose serious risks for the aquatic living organisms. The wastewater is therefore characterized by high microbial loads resulting from the series of hospital practices and by the absence of a proper treatment of the effluents produced by these hospitals. As a matter of fact, in most cases, hospital wastewater is not systematically treated before disposal in the environment, posing serious health risks and other environmental threats to the surrounding residents. It is thus of paramount importance to develop reliable methods for treating these effluents before their release into the natural environment.

\section{Acknowledgements}

This work was funded by the University of Abomey-Calavi through the Competitive Research Third Phase Program

[N 632-2018/UAC/SG/AC/SAF/VR-RU/SPRSP/SA].

\section{Availability of Data and Material}

The datasets used and/or analysed during the current study are available from the corresponding author on reasonable request.

\section{Conflicts of Interest}

The authors declare no conflict of interest.

\section{References}

[1] UNESCO (2017) Rapport mondial des Nations Unies sur la mise en valeur des ressources en eau 2017. Les eaux usées-une ressource inexploitée. UNESCO, Paris.

[2] Ministère des Affaires sociales et de la Santé (2016) Guide pratique-Pour une bonne gestion des déchets produits par les établissements de santé et médico-sociaux-Déchets issus de médicaments-Déchets liquides. Direction générale de la santé, Paris.

[3] Hartemann, P., Lopez, N. and Deblond, T. (2010) Les effluents liquides hospitaliers. Hygiène, 17, 381-386.

[4] Carvalho, I.T. and Santos, L. (2016) Antibiotics in the Aquatic Environments: A Review of the European Scenario. Environment International, 94, 736-757.

https://doi.org/10.1016/j.envint.2016.06.025 
[5] Prichard, E. and Granek, E.F. (2016) Effects of Pharmaceuticals and Personal Care Products on Marine Organisms: From Single-Species Studies to an Ecosystem-Based Approach. Environmental Science and Pollution Research, 23, 22365-22384. https://doi.org/10.1007/s11356-016-7282-0

[6] Qadouri, A., Mouhir, L. and Belkadi, M.S. (2016) Application d'une méthode d'étude quantitative et qualitative des rejets liquides hospitaliers au niveau de la Région de Marrakech Tensift El Haouz, Maroc. European Scientific Journal, 12, 110-130. https://doi.org/10.19044/esj.2016.v12n32p110

[7] Schnell, S., Bols, N.C., Barata, C. and Porte, C. (2009) Single and Combined Toxicity of Pharmaceuticals and Personal Care Products (PPCPs) on the Rainbow Trout Liver Cell Line RTL-W1. Aquatic Toxicology, 93, 244-252. https://doi.org/10.1016/j.aquatox.2009.05.007

[8] El Morhit, M. and Mouhir, L. (2014) Study of Physico-Chemical Parameters of Water in the Loukkos River Estuary (Larache, Morocco). Environmental Systems Research, 3, 1-9. https://doi.org/10.1186/s40068-014-0017-7

[9] Adanlokonon, E.A., Kanhounnon, W.G., Chabi, B.C., Adjahouinou, D.C., Koumolou, L., Bonou, B., et al. (2018) Physicochemical and Microbiological Characterization of Effluents from the "Centre Hospitalier Universitaire de la Mère et de l'Enfant Lagune (CHU-MEL)" Discharged in the Cotonou Lagoon in Benin. International Journal of Biological and Chemical Sciences, 12, 1955-1964. https://doi.org/10.4314/ijbcs.v12i4.34

[10] Akplogan, S., Johnson, R.C., Dégbey, C., Boko, M., Makoutode, M. and Fayomi, B. (2014) Assessment of the Biomedical Wastewater Treatment Station of the National University Hospital of Cotonou Benin, West Africa. Journal of Biodiversity and Environmental Sciences, 5, 157-163.

[11] Yessoufou, A. (2017) Etude diagnostique de la pollution métallique, produits pharmaceutiques et de soins personnels (ppsp) en milieux aquatiques: Cas des sédiments du lac nokoué, du déversoir d'eaux usées d'hôpital et des boues de la station d'épuration sibeau au bénin. Thèse de doctoat, Uuniversité d'abomey-calavi, Abomey Calavi.

[12] Makoutodé, M., Touré, O., Yarou, A. and d'Almeida, A.M. (2000) Traitement des déchets liquides au Centre National Hospitalier Universitaire de Cotonou au Bénin. Le Bénin Médical, 6, 29-34.

[13] Aissi, A.K., Edorh, P.A., Degbey, C., Guedenon, P., Segbo, J., Hounkpatin, A.S.Y., Boko, M. and Loko, F. (2013) Assessment of Risk Connected to the Management of Effluents from Abomey-Calavi and So-Ava Laboratories. British Journal of Applied Science \& Technology, 3, 307-319. https://doi.org/10.9734/BJAST/2014/2296

[14] The European Committee on Antimicrobial Susceptibility Testing (2018) Breakpoint Tables for Interpretation of MICs and Zone Diameters. Version 8.1, Valid from 2018-05-15. EUCAST.

[15] Organisation mondiale de la santé (2012) Directives OMS pour l'utilisation sans risque des eaux usées, des excréta et des eaux ménagères. OMS, Genève.

[16] République du Bénin (2001) Décret n² 2001-109 du 4 avril 2001 fixant les normes de qualité des eaux résiduaires en république du Bénin. Journal Officiel de la République du Bénin, 1-27.

[17] Al Aukidy, M., Verlicchi, P. and Voulvoulis, N. (2014) A Framework for the Assessment of the Environmental Risk Posed by Pharmaceuticals Originating from Hoapital Effluents. Science of the Total Environment, 493, 54-64. https://doi.org/10.1016/j.scitotenv.2014.05.128 
[18] Verlicchi, P., Al Aukidy, M., Galletti, A., Petrovic, M. and Barcel, O.D. (2012) Hospital Effluent: Investigation of the Concentrations and Distribution of Pharmaceuticals and Environmental Risk Assessment. Science of The Total Environment, 430, 109-118. https://doi.org/10.1016/j.scitotenv.2012.04.055

[19] Lim, S.R. and Schoenung, J.M. (2010) Human Health and Ecological Toxicity Potentials Due to Heavy Metal Content in Waste Electronic Devices with Flat Panel Displays. Journal of Hazardous Materials, 177, 251-259.

https://doi.org/10.1016/j.jhazmat.2009.12.025

[20] Ajit, K.P., Bhaskar, C.A. and Anil, M. (2009) Occurrence and Distribution of Bacterial Pathogens in Coastal Indicators and Waters of Orissa. Indian Journal of Marine Sciences, 38, 474-480.

[21] Tahiri, E., Benaabidate, L., Nejjari, C. and Fikri Benbrahim, K. (2009) Caractérisation des effluents liquids de l'hôpital Al Ghassani, CHU Hassan II de Fès, Maroc. Les effluents liquides des établissements de santé: État des lieux et perspectives de gestion. Chambéry.

[22] Ameziane, N. and Benaabidate, L. (2014) Caractérisation microbiologique des effluents de l'hôpital Mohamed V de Meknès et étude de leur impact sur l'environnement. Revue Nature \& Technologie, 10, 31-38.

[23] Evens, E. (2004) Evaluation des risques sanitaires et écotoxicologiques lies aux effluents hospitaliers Thèse de doctorat, Institut National des Sciences Appliquées de Lyon.

[24] Asfaw, T., Negash, L., Kahsay, A. and Weldu, Y. (2017) Antibiotic Resistant Bacteria from Treated and Untreated Hospital Wastewater at Ayder Referral Hospital, Mekelle, North Ethiopia. Advances in Microbiology, 7, 871-886. https://doi.org/10.4236/aim.2017.712067

[25] Fekadu, S., Merid, Y., Beyene, H., Teshome, W. and Gebre-Selassie, S. (2015) Assessment of Antibiotic and Disinfectant Resistant Bacteria in Hospital Wastewater, South Ethiopia. Journal of Infection in Developing Countries, 9, 149-156. https://doi.org/10.3855/jidc.4808

[26] Oliveira, H., Lopes, T., Almeida, T., Pereira, M.L. and Santos, C. (2012) Cadmium-Induced Genetic Instability in Mice Testis. Human \& Experimental Toxicology, 31, 1228-1236. https://doi.org/10.1177/0960327112445937

[27] Prozialeck, W.C. and Edwards, J.R. (2012) Mechanisms of Cadmium-Induced Proximal Tubule Injury: New Insights with Implications for Biomonitoring and Therapeutic Interventions. Journal of Pharmacology and Experimental Therapeutics, 343, 2-12. https://doi.org/10.1124/jpet.110.166769

[28] Islam, M.J., Uddin, M.S., Hakim, M.A., Das, K.K. and Hasan, M.N. (2008) Role of Untreated Liquid Hospital Waste to the Development of Antibiotic Resistant Bacteria. Journal of Innovation and Development Strategy, 2, 17-21. 